\section{Biliary motility}

\author{
P A Grace, G J Poston, R C N Williamson
}

The delivery of bile to the duodenum depends on hepatic secretion of bile plus onward propulsion through the biliary tract. Biliary kinetics involve a series of complex interrelationships between gall bladder, cystic duct, common bile duct, sphincter of Oddi and upper small intestine, with control modulation by various neural and hormonal agents. The application of modern techniques to the study of biliary motility has allowed a composite physiological picture to emerge. Moreover, alterations in biliary motility are increasingly implicated in the aetiology of gall stones and postcholecystectomy symptoms. The present review examines recent developments in the understanding of biliary motility and discusses the detailed events involved in delivering bile to the duodenum.

\section{Anatomical considerations}

The anatomy of the biliary tree has been studied extensively in several species including man. ${ }^{1-4}$ The considerable species variation in biliary structure and function should prevent uncritical extrapolation from one species to another. Most vertebrates possess hepatic ducts, cystic duct, gall bladder, common bile duct, and sphincter of Oddi, but for some reason the gall bladder is absent in certain species including horse, deer, rat, and pocket gopher. Among mammals there are three different patterns in the relationship between the termination of the bile and pancreatic ducts: (1) the two ducts join to form a common channel; (2) the common bile duct and pancreatic duct are distinct but share a common entrance into the duodenum; (3) the biliary and pancreatic ducts open separately into the duodenum. ${ }^{2}$ All three patterns can be seen in man, but type 1 predominates.

In man thickened muscle at the proximal and distal margins of the sphincter of Oddi make up the 'sphincter choledochus' and the 'sphincter ampullae' respectively. Boyden ${ }^{4}$ divided the sphincter choledochus into a superior portion, which encircles the distal common duct just before it enters the duodenum, and an inferior portion surrounding the submucosal intraduodenal portion of the common duct. The sphincter ampullae surrounds the ampullary duct at the duodenal papilla. Cineradiographic studies have shown the interaction of the various human sphincters during the passage of bile into the duodenum. ${ }^{5}$ Thus, a contraction begins in the middle of the intramural portion of the duct and propagates both upwards and downwards. The superior or retention sphincter pushes the bile in its segment up into the extramural bile duct, while the inferior or evacuation sphincter and the sphincter ampullae propel the bile in their segments into the duodenum. ${ }^{5}$

Hess ${ }^{6}$ has observed that each contraction of the human sphincter is followed by passive filling of the ampulla, which in turn is followed by another contraction. He likened this rhythmical contraction and relaxation of the sphincter segment to systole and diastole, with filling of the ampula occurring during diastole and propulsion of bile into the duodenum during systole. ${ }^{6}$ Using low compliance manometric techniques, Toouli has shown that during fasting the human sphincter of Oddi exhibits phasic contractions of peristaltic type which propel bile into the duodenum and prevent reflux of duodenal contents into the bile and pancreatic ducts.

\section{Physiological motility}

\section{BILE DUCT}

Bile flow is governed by a combination of hepatic secretion, gall bladder contraction and sphincter of Oddi activity. The biliary tract is a low pressure system undergoing minimal pressure changes, whether during fasting or after feeding, despite substantial changes in bile flow. ${ }^{38}$ The human liver secretes at least $1000 \mathrm{ml}$ of bile per day. Secretion decreases when the common duct pressure rises above $10 \mathrm{~cm}$ of water, and with occlusion of the duct the pressure stabilises at about $30 \mathrm{~cm}$ of water. ${ }^{9}$ Thus pressure is maintained at a relatively low level even in the presence of outflow obstruction. Surgeons recognise prolonged biliary obstruction by the presence of white bile, which indicates that hepatic secretion has virtually ceased, residual pigment has been reabsorbed and the duct is full of mucus derived from its own epithelium.

\section{GALL BLADDER}

\section{Pattern of emptying}

Recent data have shown that filling and emptying of the gall bladder are complex processes. The human gall bladder does not empty completely in response to food entering the duodenum, and there are frequent changes in its absolute storage volume and rate of emptying. ${ }^{10}$ Furthermore, partial emptying and refilling occur synchronously with the migrating myoelectric complex (MMC) of the intestine during the interdigestive period. Thus, entry and exit of bile from a healthy gall bladder resemble more the gentle ebb and flow of the tide than myocardial systole and diastole.

Gall bladder tone reflects the inherent compliance of the smooth muscle and fibroelastic tissue within its wall, which in turn are modulated by autonomic and hormonal mechanisms. The static compliance of the gall bladder, measured by pressure volume relationships, takes 12-16 hours to adjust to the volume of the organ. "Over shorter periods of two to four hours compliance remains relatively constant despite large fluctua- 
tions in volume." This property of slow tone adjustment would allow refilling during the period of increased bile secretion after gall bladder contraction. Gall bladder emptying starts as the stomach begins to empty, and gall bladder refilling starts when gastric emptying is nearly complete. ${ }^{12}$

Lanzini and colleagues ${ }^{10}$ have now defined the events occurring in bile flow between meals. Most hepatic bile is diverted into the gall bladder not only during fasting but also after meals. This storage process alternates at short intervals with ejection of bile from the gall bladder into the duodenum. Thus, the gall bladder behaves like a set of bellows, and this property may be important for thorough mixing of its contents.

\section{The role of cholecystokinin}

Sixty years ago Ivy and Oldberg ${ }^{13}$ observed that the intravenous injection of an extract of upper gastrointestinal mucosa caused contraction and evacuation of the gall bladder in cats and dogs. Their classical cross-circulation studies showed that acid injected into the duodenum of one animal caused gall bladder contraction in the parabiotic partner. They proposed the name 'cholecystokinin' for the hormone or active principle that caused the gall bladder to contract. In 1968 Jorpes and Mutt isolated cholecystokinin (CCK) and described the chemical sequence of its amino acids. ${ }^{14}$ Cholecystokinin is released from the duodenum by luminal acid and nutrients, in particular fat and amino acids. ${ }^{15}$ The half life of CCK in the plasma of both man and dog is about 2.5 minutes. ${ }^{15}$ The kidney is its major site of uptake from the systemic circulation. ${ }^{15}$ The predominant forms of CCK (CCK-8, CCK-33, CCK-39, and CCK-58) are all released by the upper gastrointestinal mucosa. In portacaval transposition studies in dogs, Sakamoto and colleagues showed that nearly all CCK-8 in the portal circulation is metabolised on first passage through the liver ${ }^{16}$ and maintains a systemic activity; it is probably these forms of CCK that are primarily responsible for stimulating gall bladder contraction and pancreatic secretion. ${ }^{17}$

The presence of pancreatic enzymes (particularly trypsin) inhibits CCK release from the duodenum. ${ }^{18}$ By contracting and stimulating bile flow, the gall bladder also plays a role in the negative feedback suppression of CCK release by the upper gut. In man and in dogs with bile diversion, bile salts have been shown to inhibit the endogenous release of fat stimulated CCK and neurotensin from the ileum. ${ }^{20}$ Thus, a self regulating feedback loop has been established for gall bladder emptying in response to duodenal food.

Infusions of CCK-8 cause the human gall bladder to contract, ${ }^{21}$ and the degree of change in gall bladder volume is directly proportional to the concentration of CCK detected in the plasma by radioimmunoassay. ${ }^{21}$ The volume and intraluminal pressure of the human gall bladder are inversely proportional to the circulating level of lipid-stimulated endogenous CCK. ${ }^{22}{ }^{23}$ It is now generally believed that endogenous CCK is the main driving force behind gall bladder empty- ing. ${ }^{23}$ Thus CCK regulates the length of time that bile stays in the gall bladder and remains subject to the concentrating capability of its mucosa. Cholecystokinin therefore regulates the bile acid/ cholesterol saturation index by gall bladder volume change ${ }^{24}$ rather than by altering the absorption or secretion of water and electrolytes across the gall bladder mucosa. ${ }^{25}$ So, at low bile acid secretion rates the bile secreted by the liver becomes more saturated with cholesterol: bile acid secretion rates are low when the enterohepatic circulation of bile acids is sluggish, for instance at night, as nocturnal fasting is associated with diminished CCK secretion and therefore decreased gall bladder volume changes.

Cholecystokinin acts directly on receptors in the muscle coat of the gall bladder. ${ }^{26}$ Optimal binding of ${ }^{125} \mathrm{I}-\mathrm{CCK}-33$ occurs at $\mathrm{pH} 5.5$ and requires the presence of magnesium. ${ }^{26}$ Binding of ${ }^{125}$ I-Bolton Hunter-CCK-8 to the CCK receptor requires the expenditure of cellular energy. ${ }^{27}$ There is both regional and cellular heterogeneity of CCK receptors throughout the gut. There is a 20 -fold decrease in sensitivity to the C-terminal residue of CCK-8 from gall bladder muscle to ileal circular muscle. Cholecystokinin receptors on cholingeric neurones in ileal muscle are between 80-300 times more sensitive to CCK-8 than the adjacent muscle cells. ${ }^{28}$ Multiple exposures of guinea pig gall bladder to CCK-8 appear to increase the number of CCK receptors (sensitisation), whereas in the guinea pig ileum the opposite is seen (desensitisation), associated with changes in the cholinergic receptors. ${ }^{29}$ These findings probably relate to the primary neuronal nature of CCK receptors in the ileum and the combined neuronal and muscular location of CCK receptors in the gall bladder. There is a wide range of binding capacity of CCK to its receptor between one gall bladder and another, but in general the binding affinity of ${ }^{125} \mathrm{I}-\mathrm{D}-\mathrm{Tyr}-\mathrm{Gly}-\left[(\mathrm{Nle})^{28} 30 \mathrm{CCK}-26-\right.$ 33] to gall bladder muscle has a $\mathrm{Kd}$ of around $1 \mathrm{nmol}$ and $50 \%$ of this binding can be inhibited by $0.9 \mathrm{nmol}$ CCK-8, $0.8 \mu \mathrm{mol}$ gastrin- 17 and $5 \mu \mathrm{mol}$ CCK (gastrin)-4. ${ }^{30}$ The gall bladder muscle CCK receptor has been shown by covalent cross linking studies to have a molecular weight in the region $85000-95000 .{ }^{30}$

The response of the gall bladder to CCK is calcium dependent. It is inhibited by the addition of calcium channel blocking agents. ${ }^{31}$ Removal of calcium from the extracellular fluid in gall bladder strip preparations decreases the contractile response to CCK by $80 \% .^{31}$ Hypercalcaemia induced in normal volunteers by iv infusions of calcium chloride enhances CCKstimulated gall bladder contraction in vivo. ${ }^{32}$

Gall bladder contraction in response to $\mathrm{CCK}$ is also mediated by cholinergic vagal neurones. Truncal vagotomy reduces the sensitivity of canine gall bladder to CCK (as measured by changes in intraluminal pressure). ${ }^{33}$ Truncal vagotomy may not alter the rate of gall bladder emptying, ${ }^{34}$ motility being unchanged in the early postoperative period in dogs. ${ }^{35}$ In man, however, the postcontraction volume of the gall bladder is greater after complete vagotomy, suggesting a parasympathetic role in normal emptying. ${ }^{34}$ 
Not only does vagal stimulation facilitate the response of the gall bladder to $\mathrm{CCK}$, but it may also regulate this response. ${ }^{36}$ Using ultrasound it can be shown that sham feeding stimulates gall bladder emptying in up to $50 \%$ of people, suggesting a major role for vagal activity in gall bladder motility. This response is eliminated by cholinergic blockade with atropine, again suggesting that the vagus can stimulate the gall bladder to contract. ${ }^{37}$ Cholecystokinin receptors on cholinergic postganglionic parasympathetic neurones are much more important in mediating the response of the gall bladder to CCK than they are in mediating the response of pancreatic acini to this hormone. ${ }^{38}$ Either hypersensitivity of the gall bladder to CCK or hyposensitivity of the sphincter of Oddi to CCK (resulting in the gall bladder contracting against a closed biliary system) may be the cause of acalculous biliary colic in the small group of patients whose symptoms can be reproduced by CCK infusion and who benefit from cholecystectomy. ${ }^{39}$

\section{Other neurohumoral agents}

Other gastrointestinal peptides and neurotransmitters have either cholecystokinetic actions (direct and/or CCK potentiating) or cholecystostatic actions (direct and/or CCK inhibiting). Gastrin-17 belongs to the same family of peptides as CCK. It causes gall bladder muscle contraction in some species, though much less potently than $\mathrm{CCK}^{40}$ and not at all in man. ${ }^{41}$ Secretin, released from the upper gut by the presence of acid, abolishes the net water absorption from bile in the gall bladder. ${ }^{42}$ On its own secretin has no effect on gall bladder muscle, ${ }^{4243}$ but it has been shown to potentiate the action of CCK on the gall bladder. ${ }^{44}$ Substance $P$ is a direct stimulant of gall bladder contraction in both dogs and rabbits, ${ }^{45}$ but its cholecystokinetic potency is only about one 600 th that of CCK. ${ }^{+6}$ Similarly motilin is weakly cholecystokinetic, but this effect is limited to the quiescent period between meals. ${ }^{47}$ The response of the gall bladder to neurotensin is species-specific. In dogs it causes gall bladder contraction with about one 50th the potency of CCK. ${ }^{48}$ In man, neurotensin causes gall bladder relaxation in vivo, but this appears to be an indirect effect as neurotensin produces no response in vitro. ${ }^{49}$ Histamine $\left(\mathrm{H}_{1}\right)$ receptor stimulation causes gall bladder muscle contraction, whereas stimulation of type 2 receptors $\left(\mathrm{H}_{2}\right)$ causes gall bladder muscle relaxation. ${ }^{50}$

Pancreatic polypeptide causes relaxation of the gall bladder and decreased intraluminal pressure, ${ }^{51}$ which encourages refilling after contraction. ${ }^{52}$ Infusions of CCK in man bring about release of pancreatic polypeptide, as measured by radioimmunoassay. ${ }^{53}$ Pancreatic polypeptide remains raised for up to six hours after a meal, suggesting that pancreatic polypeptide could play a role in the regulation of postprandial gall bladder filling. ${ }^{52}$ Vasoactive intestinal peptide decreases resting gall bladder pressure in a dosedependent manner, eliminating spontaneous contractile activity. ${ }^{54}$ Vasoactive intestinal polypeptide inhibits the contractile response of the gall bladder to CCK in vivo ${ }^{545}$ and in vitro. ${ }^{56}$ The gall bladder is supplied by three types of vagal nerve fibre: cholinergic, CCK-ergic and VIPergic. Thus vagally regulated gall bladder tone and contraction is the net result of the interplay of stimulatory fibres (mediated by acetylcholine and CCK) and inhibitory fibres (mediated by vasoactive intestinal polypeptide). ${ }^{55}$ Besides diminishing the hepatic secretion of bile, ${ }^{57}$ somatostatin is a potent inhibitor of gall bladder emptying in man, whether meal-stimulated, vagally-mediated or CCK-induced. ${ }^{58}$ Peptide YY has recently been shown to potentiate gall bladder relaxation and refilling after CCKinduced contraction, ${ }^{59}$ and calcitonin gene related peptide ${ }^{60}$ and pancreastatin ${ }^{61}$ inhibit CCK-induced gall bladder contraction in the guinea pig.

\section{SPHINCTER OF ODDI}

The role of the sphincter of Oddi is to regulate bile flow into the duodenum, divert hepatic bile into the gall bladder and prevent reflux of duodenal contents into the biliary tree. ${ }^{3}$ The physiological sphincter of Oddi is characterised by a high pressure zone located at the choledochoduodenal junction. ${ }^{62}{ }^{63}$ Physiological studies of the sphincter of Oddi have centred on three main areas: (1) the relationship between sphincter of Oddi activity and the activity of the surrounding duodenum; (2) the mechanism by which the sphincter controls the flow of bile into the duodenum, and (3) the factors that control sphincter of Oddi function.

\section{Functional independence of the sphincter}

Early investigators ${ }^{64}$ considered biliary flow to be solely dependent on changes in duodenal tone and muscular activity. Others held that the sphincter of Oddi was functionally independent of the duodenal musculature and was responsible for changes in biliary pressure. ${ }^{65-67}$ More recently, Mochinaga and colleagues ${ }^{68}$ have shown that in the fasted state gastroduodenal motor activity plays a role in the regulation of bile flow. Using a canine model they observed that bile entered the duodenum only when the duodenal wall at the level of the choledochoduodenal junction was not contracting or when the amplitude of contraction was small compared with the maximum amplitude of contraction during phase III, the active phase of the MMC. They therefore suggested that when the duodenal wall contracts, it constricts the common bile duct and the cholechoduodenal junction to impede bile flow. Others have showed a pylorocholecystic reflex ${ }^{69}$ and another a gastrosphincter of Oddi reflex, ${ }^{70}$ indicating a relationship between gastrointestinal and sphincter of Oddi motility.

Both morphine and noradrenaline contract the sphincter but relax the duodenum. ${ }^{71}$ These findings were confirmed by studying the effect of adrenaline and noradrenaline on the isolated terminal bile duct. ${ }^{72}$ Ono and colleagues simultaneously recorded bile flow and electrical activity from the sphincter and duodenum in humans. They found a negative correlation between bile flow and sphincter of Oddi elec- 
trical activity - that is, bile flowed into the duodenum only in the absence of sphincter electrical activity. ${ }^{73}$ Nevertheless, it seems reasonable to assume that the activity of the duodenal musculature can modify the rate of bile delivery into the duodenum.

\section{Bile flow into the duodenum}

Several studies in animals and man show that the sphincter of Oddi has spontaneous phasic contractions. ${ }^{740}$ In man these phasic contractions occur at about four/minute and have a duration of four to five seconds. ${ }^{75}$ Using a triple lumen catheter with orifices spaced at $2 \mathrm{~mm}$ intervals from the distal end for manometric measurements, Toouli and his colleagues found that $60 \%$ of human phasic pressure waves propagate towards the duodenum, $14 \%$ propagate in a retrograde fashion towards the common bile duct while $26 \%$ are simultaneous - that is, propagate in both directions at once. ${ }^{81}$ Species differences in phasic wave direction make the physiological purpose of this phenomenon unclear. In dogs the biliary sphincter may act as a pump to expel bile into the duodenum, ${ }^{82}$ yet it has also been observed that flow through the common bile duct stops with each phasic contraction of the sphincter. ${ }^{7378183}$ Moreover in cats, increased sphincter activity is associated with increased resistance to flow through the choledochoduodenal junction. ${ }^{71}$

These apparent contradictions have now been resolved by Toouli's simultaneous analysis of the opossum sphincter, using cine-radiography, transphincteric flow and electromyographic recordings. ${ }^{84}$ The main mechanism of common bile duct emptying in the opossum is antegrade contraction of the sphincter of Oddi. A wave of contraction begins at the junction of the bile duct and sphincter and strips the contents of the sphincter segment into the duodenum (the systolic phase). During sphincter contraction no flow occurs from the bile duct into the sphincter segment. The sphincter then relaxes, and there is passive flow of bile from the duct into the sphincter segment (the diastolic phase). A wave of contraction then begins again at the ductal/ sphincter junction, and the cycle repeats itself. The overall effect of phasic contractions is therefore to promote flow from the common bile duct into the duodenum. Initially, increased contractions are accompanied by increased flow across the sphincter; but when the contractions exceed a certain level, the diastolic interval is abolished completely and flow ceases. In the opossum, this phenomenon occurs when the frequency of contractions exceeds eight $/ \mathrm{min}$. $^{7}$

A similar phenomenon has been described in dogs. ${ }^{85}$ Intense phasic motor activity appears to impede bile flow, whereas less intense activity facilitates flow. Although species differences probably exist, the radiological studies of Torsolis and Hess ${ }^{6}$ and the manometric observations of Toouli and colleagues ${ }^{81}$ indicate that the human sphincter of Oddi also exhibits peristaltic phasic contractions, which propel bile into the duodenum and prevent reflex of duodenal contents into the bile and pancreatic ducts. Thus, the purpose of phasic waves appears to be the promotion of bile flow through the sphincter of Oddi into the duodenum.

\section{Control mechanisms}

The activity of the sphincter of Oddi is subject to many influences. In 1917 Meltzer proposed his 'Law of contrary innervation' whereby reciprocal contraction of the gall bladder and relaxation of the sphincter of Oddi was due to a fine nervous mechanism. Potter and $M^{2} n^{64}$ observed that perception of food caused a reduction in resistance to bile flow, again indicating a neural influence on the sphincter. In 1926 Whitaker demonstrated, however, that the denervated gall bladder can still contract in response to food. ${ }^{86}$

Sandblom showed the hormonal action of cholecystokinin on the sphincter of Oddi in $1935 .{ }^{87}$ Since then, several other hormones including secretin, ${ }^{75}$ pentagastrin,${ }^{88}$ serotonin,${ }^{89}$ caerulein, ${ }^{88}$ glucagon $^{75}$ and motilin $^{90}$ have all been shown to affect the sphincteric activity. A role of neural mediation has reemerged from recent work showing regulation of the sphincter by excitatory and inhibitory pathways. ${ }^{91}$ Humoral and neural stimuli are in any case likely to be interlinked.

\section{(a) Hormonal factors}

The response of the sphincter of Oddi to CCK varies according to species. In man CCK decreases phasic wave activity and reduces baseline pressure, ${ }^{75}$ while a similar response is found in primates $^{76}$ and cats. ${ }^{77}$ In these species the sphincter relaxes in response to $\mathrm{CCK}$, thus facilitating the passive flow of bile from the common duct into the duodenum. The effect of CCK in the rabbit, ${ }^{78}$ opossum ${ }^{79}$ and prairie dog, ${ }^{92}$ however, is to increase the phasic wave activity of the sphincter without affecting baseline pressure. In these species increased sphincter of Oddi activity propels bile actively into the duodenum in response to CCK.

Until recently, the inhibitory actions of CCK on the sphincter of Oddi were thought to be caused by a direct action of the hormone on the sphincter muscle. New data now show that the effects of CCK on the sphincter of Oddi are mediated by non-adrenergic, non-cholinergic neurones that inhibit the feline sphincter of Oddi. This effect masks a direct excitatory effect of CCK on the sphincter muscle. ${ }^{77}$ In the opossum, on the other hand, excitation of the sphincter of Oddi by CCK appears to be the result of a direct action of the hormone on the sphincter muscle. ${ }^{3}$

Other gastrointestical hormones and peptides can also affect the sphincter of Oddi. Caerulein is a potent inhibitor of sphincter activity in a number of species. ${ }^{889} 94$ Gastrin, which shares an identical carboxyterminal pentapeptide with CCK and caerulein, also influences the choledochal sphincter. ${ }^{88}$ The potency of this hormone, however, is considerably less than that of CCK or caerulein. Agosti et $a l^{94}$ showed that human gastrin has only $10-40 \%$ of the activity of CCK in relaxing the sphincter of Oddi in the anaesthetised guinea pig. Secretin reduces sphincter resistance in the dog, probably indirectly by 
potentiating the action of CCK. Glucagon also decreases sphincter resistance in $\operatorname{dogs}^{88}$ and man, ${ }^{63}$ and it is often used to relax the sphincter to facilitate cannulation during ERCP. ${ }^{3}$ Recently, motilin, serum concentrations of which fluctuate with phases of the interdigestive MMC, has also been found to influence the sphincter of Oddi. ${ }^{390}$ In the dog ${ }^{85}$ and opossum ${ }^{95}$ phasic contractions exhibit cyclical variations in phase with the interdigestive MMC. Thus, the physiological role of motilin on the sphincter of Oddi may be to regulate this cyclical activity during the interdigestive period. The actions of motilin on the sphincter of Oddi may be mediated by an intramural excitatory pathway, which appears to consist of opiate, serotoninergic and cholinergic neurones. $\%$

The effects of pancreatic polypeptide, peptide-YY, and neuropeptide-Y on biliary motility are controversial. Both pancreatic polypeptide and peptide-YY have been shown to enhance gall bladder filling in the prairie dog. ${ }^{97} 98$ Tatemoto and Mutt reported that peptide-YY stimulates gall bladder contraction in vitro ${ }^{99}$ but does not affect CCK-8-stimulated gall bladder contraction in the anaesthetised guinea pig. ${ }^{100}$ Likewise, peptide-YY does not influence resting gall bladder tension or CCK-stimulated gall bladder contraction in dogs; ${ }^{101}$ we have shown similar results in the prairie dog. ${ }^{102}$ Nonetheless, peptide-YY inhibits the increase in phasic contractions of the sphincter usually observed with CCK-8. Thus, pancreatic polypeptide and peptide-YY may play a role in modulating biliary motility in the postprandial state by inhibiting bile flow into the duodenum and promoting gall bladder filling. Since neuropeptide-Y increases sphincter of Oddi activity and gall bladder pressure in the prairie $\operatorname{dog},{ }^{103}$ it could be a neurotransmitter or neuromodulator regulating bile flow.

\section{(b) Neural factors}

Perception of food causes a reduction in the resistance to bile flow through the choledochoduodenal junction, ${ }^{64}$ indicating a neural influence on the biliary sphincter. Recent neurohistochemical studies have shown both adrenergic and cholinergic neurones within the sphincter of Oddi of the cat and dog. ${ }^{104}$ Persson ${ }^{105}$ suggests that the cat gall bladder and sphincter contain both adrenergic $\alpha$-receptors (mediating contraction) and adrenergic $\beta$-receptors (mediating relaxation). In the gall bladder $\beta$-receptors predominate, while in the sphincter $\alpha$ - and $\beta$ receptors are more evenly distributed. Relaxation of the sphincter in response to adrenergic stimulation, however ( $\beta$-receptors), occurs only when the $\alpha$-receptors have previously been blocked with phenoxybenzamine. ${ }^{105}$ Although both receptor types exist in sphincter smooth muscle, mainly $\alpha$-adrenoreceptors are activated by sympathetic nerve stimulation. Thus, adrenergic stimulation causes the sphincter of Oddi to contract and the gall bladder to relax. This mechanism may be important during gall bladder filling by promoting the entry of bile into the gall bladder.
The biliary tract receives a parasympathetic innervation from the vagus nerve. ${ }^{106}$ Acetylcholine contracts both the gall bladder and the sphincter of Oddi in the cat and calf. ${ }^{72} 106107$ Cholinergic stimulation of the sphincter by bethanecol increases the frequency of phasic contractions in the opossum. ${ }^{84}$ The function of the vagus nerve in sphincter of Oddi function remains obscure, ${ }^{108} 109$ though recent work in the prairie dog has demonstrated increased resistance to flow through the sphincter after truncal vagotomy.$^{80}$ Vagal stimulation studies have also failed to define clearly the role of the vagus in biliary dynamics. Some investigators have reported sphincter contraction during vagal stimulation, ${ }^{110}$ but others could not detect any response to either central or peripheral stimulation of the vagus. ${ }^{\prime \prime \prime}$

Behar and Biancani have suggested the presence of non-cholinergic, non-adrenergic neurones in the sphincter of Oddi. ${ }^{77}$ Studying the feline sphincter of Oddi, they observed that CK-induced sphincter relaxation was not antagonised by either adrenergic or cholinergic blockade. Either CCK has a direct action on sphincteric smooth muscle, therefore, or its effects are mediated by a different neurotransmitter. In support of such a neurological pathway, administration of tetrodotoxin, which blocks nerve transmission without affecting smooth muscle, completely antagonised the effects of CCK on the sphincter. ${ }^{77}$

\section{(c) Pharmacological factors}

Morphine has long been known to increase resistance to bile flow. Studies in a number of species ${ }^{71}{ }^{82}$ have shown that the sphincter of Oddi is very sensitive to opiates, responding with marked contractions to low doses of morphine sulphate. In man small doses of morphine increase the rate of phasic contractions of the sphincter of Oddi; ${ }^{3}$ phasic wave amplitude and baseline pressure are also increased. ${ }^{112}$ Thus, morphine is contraindicated in the management of biliary pain. Pethidine also produces a marked rise in biliary pressure but its effect is only half that of morphine. ${ }^{113}$ Amyl nitrate consistently relaxes the sphincter of Oddi across several species. ${ }^{83111114}$ This inhibitory effect has been used clinically to distinguish sphincter spasm from stenosis.

Nifedipine, a calcium channel blocker, has also been shown to reduce baseline sphincter of Oddi pressure as well as the frequency, amplitude and duration of phasic contractions." Intravenous butylscopolamine bromide (given iv) will decrease sphincter of Oddi motility without affecting baseline pressure. ${ }^{116}$ Alcohol administered either iv or into the duodenum causes a moderate decrease in baseline pressure without affecting sphincter motility. ${ }^{116}$ Recent endoscopic manometry in humans given pentazocine has shown higher baseline pressures and increased amplitude of phasic contractions in the sphincter. ${ }^{117}$ Fentanyl has also been associated with sphincter spasm during peroperative cholangiograaphy, ${ }^{118}$ whereas diazepam is without such effects. ${ }^{63}$ 
Various anaesthetic agents influence sphincter of Oddi function. Thus small iv doses of barbiturate increase flow through the sphincter. ${ }^{119}$ Xylazine and ketamine affect biliary tract motility in the prairie dog and should therefore be avoided during physiological studies of the sphincter. ${ }^{120}{ }^{121}$ Lastly, a recent study in dogs has shown inhibition of endogenous CCK release by several different anaesthetic agents (with the exception of a-chlorolose), which may therefore affect sphincter motility indirectly. ${ }^{122}$

\section{(d) Physical factors}

Temperature affects sphincter of Oddi activity in rabbits, cold being inhibitory and a rise to $40^{\circ} \mathrm{C}$ being stimulatory. ${ }^{83}$ Increasing the blood pressure in dogs by infusing saline raises sphincter opening pressure, whereas hypotension produced by haemorrhage diminishes opening pressure. ${ }^{111}$ That sphincter activity is influenced by the degree of gall bladder filling is well established. ${ }^{792119}$ In the prairie dog, for example, distending the gall bladder increases sphincter activity and emptying it has the opposite effect, the so-called cholecystosphincter of Oddi reflex. ${ }^{74} \mathrm{~A}$ relationship has recently been shown between sphincter of Oddi activity and the interdigestive or migrating myoelectric complex. ${ }^{95} 123$ Two groups of investigators have shown in the conscious opossum that phasic contractions are synchronous with spike potentials in the sphincter and that both exhibit cyclical changes that correlate with the MMC. ${ }^{95} 123$ Using a canine model, Mochinaga has demonstrated a relationship between gastroduodenal motor activity and bile flow. ${ }^{68}$

\section{(e) Intraluminal stimuli}

Early investigators observed that introduction of acid into the stomach increased resistance to bile flow entering the duodenum in the anaesthetised dog, whereas alkali achieved the reverse. ${ }^{124}$ In patients with previous cholecystectomy installation of dilute hydrochloric acid into the duodenum causes a transient increase in sphincter of Oddi resistance, which can be blocked with atropine. ${ }^{125}$

Fifty years ago, Best and Hicken ${ }^{126}$ inferred from cholangiographic evidence that cream and olive oil relax the human sphincter of Oddi, but Doubilet could not confirm this finding in patients after cholecystectomy. ${ }^{125} \mathrm{~A}$ more extensive investigation of cholecystectomy patients showed that an egg yolk meal caused relaxation but olive oil did not; protein also caused slight relaxation of the sphincter, but carbohydrate had no effect. ${ }^{114}$ Recent work in the prairie dog has shown that intraduodenal infusions of acidified saline $^{127}$ and sodium oleate ${ }^{128}$ decrease sphincter of Oddi activity, whereas protein infusions stimulate sphincter activity. ${ }^{129}$ Exogenous CCK consistently increases sphincter of Oddi activity in this species. ${ }^{902}$ These conflicting data may be explained by evidence in rodents that $\mathrm{CCK}$ is not released after ingestion of fats but is released by protein. ${ }^{130}$

\section{Pathophysiology}

\section{DYSMOTILITY AND GALL STONES}

In 1856 Meckel von Helmsbach proposed that mucus might form a nidus, but that stasis was necessary for cholesterol to 'adhere' to this and create a gall stone. "It has been argued that the presence of established calculi affects neither the physiology of biliary constituents (bile salts, cholesterol and phospholipids) nor the contractility of gall bladder muscle. ${ }^{131}$ Whether alterations in gall bladder contractility play an aetiological role in gall stone formation is controversial. One survey has shown increased postprandial emptying of the gall bladder in patients with cholesterol stones. ${ }^{132}$ These authors suggested that such an increase in gall bladder emptying would be associated with a decreased bile acid pool and in turn precipitate lithiasis. These patients also had increased gall bladder sensitivity to CCK. ${ }^{133}$ Another group found unchanged gall bladder sensitivity to CCK in vivo but altered contractility in response to CCK in vitro; contractility increased in early disease but decreased in advanced disease. ${ }^{134}$ These data $^{132-134}$ are, however, at variance to the majority of published studies on the correlation between altered gall bladder motility and gall stone formation.

Many clinical and experimental studies confirm decreased gall bladder emptying in the presence of gall stones. ${ }^{135-142}$ In the prairie dog, prevention of stasis by periodic administration of CCK lowers the incidence of gall stones. ${ }^{135}$ Increased resistance to flow in the cystic duct delays gall bladder emptying and predisposes to calculi. ${ }^{143}$ Increased viscosity of gall bladder bile may result from hyperconcentration during delayed emptying. ${ }^{144}$ Calculous gall bladders have diminished sensitivity to prostaglandin stimulation of smooth muscle contraction, ${ }^{145}$ but prostaglandins are not the prime mediators of gall bladder emptying. Patients with gall stones have raised CCK concentration in their duodenal mucosa compared with normal controls. ${ }^{146}$ This may be because of increased synthesis of CCK in order to promote gall bladder emptying if the gall bladder is less sensitive to CCK, or alternatively it may be because of a failure to release CCK which results in poor gall bladder emptying in response to the presence of food and acid in the duodenum. On balance, we favour the former hypothesis. During gall stone formation in the prairie dog, changes in gall bladder motility precede changes in bile salt pool size. ${ }^{147}$ Dysmotility may reflect a diminished contractile response to $\mathrm{CCK}^{148}$ rather than alterations in membrane excitation, excitation-contraction coupling or total content of contractile proteins in gall bladder muscle.

Thompson and colleagues ${ }^{137}$ have described a group of gall stone patients whose gall bladders failed to contract with the normal endogenous release of CCK after a fat meal. They termed these patients 'non-contractors'. CCK-induced contraction of their gall bladder muscle strips were correlated with the preoperative contractility of the gall bladder in response to endogenous CCK. 'Non-contractors' were shown to have fewer CCK receptors in gall bladder muscle 
than other gall stone patients whose gall bladders contracted normally to endogenous CCK. In the guinea pig too, experimental cholelithiasis is associated with decreased biliary motility owing to fewer CCK receptors. ${ }^{149}$

After major abdominal operations reductions in bowel motility, CCK release and vagal activity could all lead to gall bladder hypotonicity and biliary stasis predisposing to gall stones. ${ }^{150}$ Reduced motility of gall bladder and intestines alike may contribute to gall stone formation after truncal vagotomy, when increased resistance at the sphincter of Oddi ${ }^{80}$ and gall bladder dilatation $^{151}$ may both be factors. Patients receiving prolonged total parenteral nutrition are also at risk of rapid gall stone formation; bile stasis appears to be the major aetiological event. ${ }^{150} 152$ Interestingly, children on longterm total parenteral nutrition seldom develop gall stones unless other aetiological factors are also present for example, necrotising enterocolitis or distal ileal resection resulting in reduced bile salt pool or biliary stasis. ${ }^{153} 154$ The frequency and severity of acute cholecystitis, both calculous and acalculous, in seriously ill patients after trauma or major surgery necessitate urgent ultrasonography and prompt cholecystectomy if the diagnosis is suspected. ${ }^{155}$ Daily administration of CCK to patients on longterm total parenteral nutrition might prevent this complication. ${ }^{156}$

One interpretation of the evidence that implicates altered biliary motility in the aetiology of gall stone formation is that gall bladder activity must be maintained in a tight narrow band between overactivity reducing the bile acid pool with consequent lithiasis, ${ }^{132-134}$ and underactivity causing stasis and gall stone precipitation. . $^{135-156}$ Furthermore, as argued earlier, a reduction in the rate of turnover of the enterohepatic circulation of bile acids is associated with reduced hepatic bile acid secretion, so on balance we support the view that decreased biliary motility rather than increased biliary motility is the aetiological event in cholelithiasis.

\section{BILIARY MOTILITY AND AGEING}

Boyden and Grantham investigated the effect of age on gall bladder emptying in $1926,{ }^{157}$ using oral cholecystography after a standard 'Boyden meal' (five egg yolks well stirred in half a pint of cream). The rate of gall bladder emptying decreased sharply between childhood and adulthood but remained constant thereafter. When cholecystograms were reviewed from subjects aged 60-83 years, a quarter of those without gall stones had evidence of delayed emptying. ${ }^{158}$ In support, both fasting and corn oil-stimulated concentrations of CCK in plasma are higher in older than younger healthy volunteers, though ultrasonic estimates of gall bladder volume were similar. ${ }^{159}$ The CCK content of upper small bowel mucosa increases progressively with age in normal human subjects ${ }^{146}$ and guinea pigs, ${ }^{160}$ although it is not known if this is the result of increased synthesis or decreased release of CCK. The in vitro response of rabbit gall bladder strips to CCK diminishes between six months and four years of age ${ }^{161}$ and in the guinea pig in vivo there is an age related loss of gall bladder sensitivity and contractility to exogenous CCK owing to a decrease in gall bladder CCK receptors. ${ }^{162}$ Although age lessens the sensitivity of gall bladder muscle to CCK, therefore, there is a compensatory increase in CCK release, which maintains near normal gall bladder emptying.

The mechanism that correlates the age related decrease in gall gladder emptying to increased compensatory CCK release is probably the bile salt inhibition of CCK release postulated by Gomez and colleagues. ${ }^{20}$ Decreased gall bladder emptying results in less bile salts reaching the duodenum and therefore greater CCK release. In extreme youth the gall bladder response to CCK is different. Ultrasonography has been used to measure the contraction of both maternal and near term fetal human gall bladders in response to a standard maternal meal. ${ }^{163}$ Maternal gall bladder size decreases, but fetal gall bladder size is unchanged. It is not known if maternal CCK can cross the placenta. Indeed, whether any derivatives of the maternal meal can reach CCK cells in the fetal duodenum in sufficient quantities is unknown, likewise nothing is known of the ontogeny of CCK physiology during embryonic development in man. In guinea pigs the magnitude of contractile response of gall bladder strips to various stimulants (including CCK) increases progressively from the preterm fetus to the mature adult. ${ }^{164}$ These data indicate that cholinergic and CCK receptors are present and functional before birth, but the contractile power of gall bladder muscle continues to develop after birth. Certainly, in the guinea pig gall bladder CCK receptors decline in number with advancing age. ${ }^{162}$

A possible aetiological factor in the biliary stasis of ageing is the presence of duodenal juxtapapillary diverticula. ${ }^{165}$ The association between such diverticula and common bile duct stones is well documented; ${ }^{165}$ perhaps dysfunction of the sphincter of Oddi allows reflux of duodenal contents into the lower common bile duct. ${ }^{166} \mathrm{We}$ have shown that the rate of development of experimental gall stones in the guinea pig correlates directly with age and can be prevented by administration of CCK to provoke biliary emptying. ${ }^{167}$

CHOLECYSTECTOMY AND THE SPHINCTER OF ODDI

Nearly half a million cholecystectomies are performed each year in the United States, ${ }^{168}$ yet very little is known about the effect of this operation on the sphincter of Oddi. Ruggero Oddi was the first to observe that cholecystectomy resulted in marked dilatation of the common bile duct in dogs: ${ }^{169}$ 'La bile se recueille dans la vésicule biliare ou dans les conduits biliares trés dilatables des animaux qui manquent de cette derniére'. These findings were confirmed by Judd and Mann, who also found increased luminal pressure in the bile duct. ${ }^{170}$ Subsequent work has also shown that the common bile duct dilates in animals after cholecystectomy, ${ }^{171}$ but autopsy and radiological studies in man do not confirm a clear cut effect. ${ }^{172}{ }^{173}$ Patients with choledocholithiasis have recently been shown to have greater 
TABLE Sphincter of Oddidysfunction

\begin{tabular}{|c|c|c|c|}
\hline & \multirow{2}{*}{$\frac{\text { Structural }}{\text { Biliary I }}$} & \multicolumn{2}{|l|}{ Functional } \\
\hline & & Biliary II & Biliary III \\
\hline \multirow[t]{3}{*}{ Presentation } & 1 Biliary type pain & 1 Biliary type pain & 1 Biliary type pain only \\
\hline & 2 Abnormal LFTs on 2 occasions & 2 Abnormal LFTs on 2 occasions & \\
\hline & $\begin{array}{l}3 \text { Delayed drainage of contrast } \\
\text { on ERCP }>45 \mathrm{~min}\end{array}$ & $\begin{array}{l}3 \text { Delayed drainage on contrast } \\
\text { on ERCP }>45 \mathrm{~min} \\
\text { or }\end{array}$ & \\
\hline \multirow[t]{2}{*}{ Manometry } & $\begin{array}{l}4 \text { Dilated CBD }>12 \mathrm{~mm} \\
\text { Optional }\end{array}$ & $\begin{array}{l}4 \text { Dilated CBD }>12 \mathrm{~mm} \\
\text { Necessary for diagnosis } \\
1 \text { Elevated SO basal pressure }\end{array}$ & $\begin{array}{l}\text { Mandatory } \\
1 \text { SO hypertonicity or } \\
\text { spasm }\end{array}$ \\
\hline & & $\begin{array}{l}2 \text { Reduction of pressure or SO } \\
\text { phasic wave amplitude with } \\
\text { CCK-OP or amylnitrite }\end{array}$ & $\begin{array}{l}2 \text { Paradoxical response } \\
\text { to CCK-OP } \\
3 \text { SO tachyoddia } \\
4 \text { Altered SO phasic } \\
\text { wave sequence }\end{array}$ \\
\hline Treatment & Operative sphincteroplasty & \multicolumn{2}{|c|}{ Endoscopic sphincterotomy } \\
\hline
\end{tabular}

LFTs = liver function tests; $\mathrm{ERCP}=$ endoscopic retrograde cholangiopancreatography $\mathrm{CBD}=$ common bile duct; $\mathrm{SO}=$ sphincter of Oddi; CCK-OP $=$ cholecystokinin octapeptide

common duct diameters than normal volunteers, and it appears that after cholecystectomy further dilatation of these ducts occurs in the absence of symptoms. ${ }^{174}$

Recent studies have shown the presence of a cholecystosphincteric reflex suggesting that sphincter activity is mediated, at least in part, by the degree of gall bladder distension..$^{7119}$ Furthermore, in dogs CCK release is increased in response to fat stimulation after cholecystectomy. ${ }^{175}$ This finding could reflect loss of bile salt inhibition of CCK release, ${ }^{20}$ as bile salt flow will no longer surge when the gall bladder empties after a meal. In prairie dogs the sphincter of Oddi behaves differently after cholecystectomy, with altered responses to $\mathrm{CCK}$ and intraduodenal fat. ${ }^{128}$

'POST CHOLECYSTECTOMY SYNDROME' Although cholecystectomy is a safe and effective operation, $20 \%$ of patients develop either new gastrointestinal symptoms or recurrence of the symptoms for which the operation was recommended. ${ }^{176}$ This unfortunate outcome has been referred to as 'the post cholecystectomy syndrome', but it is unlikely that there is such a specific entity. Many non-biliary conditions can mimic the symptoms of biliary tract disease and should be considered in the differential diagnosis of such patients. These include pancreatitis, peptic ulcer, reflux oesophagitis, right sided colonic diverticulosis and the irritable bowel syndrome. ${ }^{177}$ Common duct stones, retained gall bladder and traumatic stricture of the bile duct are obvious potential explanations for post cholecystectomy problems. Although a long cystic duct remnant is sometimes implicated, ${ }^{176}$ the evidence is unconvincing unless stones are contained in the stump. ${ }^{177}$ Some patients with post cholecystectomy symptoms may have motor dysfunction of the sphincter, including papillary stenosis and biliary dyskinesia.

PAPILLARY STENOSIS

Papillary stenosis has been defined as a narrowing of all or part of the sphincter of Oddi segment. ${ }^{178}$ This is a structural problem resulting from fibrosis of the sphincter. Aetiological factors include injury by impacted stones or operative instrumentation, infected bile and pancreatitis. ${ }^{178-181}$

To distinguish organic stenosis from biliary dyskinesia, Hogan and Geenen have proposed a classification based on clinical, laboratory and radiological findings which recognises three groups of patients ${ }^{178}$ (Table): group I patients have biliary pain, abnormal liver function tests on two or more occasions, delayed drainage of ERCP contrast beyond 45 minutes and a dilated common bile duct $>12 \mathrm{~mm}$ in diameter. These patients are likely to have a structural problem, ie papillary stenosis, and manometry is optional. Group II patients have biliary pain but only one or two of the other criteria. As their lesion could be structural or functional, sphincter of Oddi manometry helps to separate the two. Raised baseline pressures which decrease with iv CCKOP $(20 \mathrm{ng} / \mathrm{kg})$ or inhalation of amyl nitrite indicate a functional rather than a structural abnormality, but in either case endoscopic sphincterotomy may be beneficial. ${ }^{178}$ Group III patients present only with biliary pain and probably have 'true' sphincter of Oddi dyskinesia; manometry is essential to define the abnormality, and again endoscopic sphincterotomy may be helpful. ${ }^{178}$

Fibrosis and inflammation of the papilla of Vater have often been documented at operation and may be associated with biliary tract disease and/or recurrent acute pancreatitis. ${ }^{182-185}$ Symptoms do not, however, necessarily coincide with the severity of histological change. ${ }^{183}$ In a prospective study of 28 patients with postcholecystectomy pain, Moody found an abnormal papilla in $82 \% .{ }^{184}$ Anterior sphincteroplasty and transampullary septectomy gave longterm relief of pain or symptomatic improvement in $76 \%$ of patients, ${ }^{186}$ and we too have found this operation beneficial. ${ }^{185}$ Nonetheless, the extensive amount of collagen that is normally present within the papilla makes the histological diagnosis of fibrosis difficult, ${ }^{182}$ so that a clear cut differentiation from biliary dyskinesia is not always possible. 


\section{BIL IARY DYSKINESIA}

Biliary dyskinesia is defined as a primary disorder of the tonic or phasic motor activity of the sphincter of Oddi. ${ }^{178}$ Long suspected as a source of abdominal pain after cholecystectomy, sphincter spasm was described by Parvel in 1932 and termed biliary dyskinesia by Ivy and Sandblom two years later. ${ }^{187}$ In early radiographic and manometric studies of eight patients with T-tubes, McGowan and colleagues observed that morphine provoked a rapid rise in intrabiliary pressure associated (in one patient) with severe epigastric pain similar to that experienced before cholecystectomy. ${ }^{188}$ Furthermore, unprovoked episodes of pain were also associated with a marked rise in intrabiliary pressure. These classical studies indicated a pivotal role for the sphincter of Oddi in raising intrabiliary pressure and causing abdominal pain. The hypothesis was soon supported by Colp's observation that sphincterotomy could often relieve post cholecystectomy pain ${ }^{189}$ and by Dahl-Iverson's discovery that with an intact sphincter patients with presumed biliary dyskinesia could still experience episodic pain even with a $\mathrm{T}$-tube to provide dependent drainage. ${ }^{190}$

Attempts to identify biliary dyskinesia by pharmacological provocation of pain or pancreatic enzyme changes have had varying success. Nardi and Acosta introduced the morphine-neostigmine provocation test in which papillary contraction is stimulated by morphine and pancreatic secretion by neostigmine. ${ }^{191}$ In one series 16 of 23 patients with abdominal pain and a positive Nardi test had moderate to marked signs of papillary stenosis on endoscopic evaluation. ${ }^{192}$ Other investigators have found this test much less specific, either failing to confirm any correlation with papillary stenosis at operation ${ }^{193}$ or finding positive tests in $60 \%$ of healthy controls and patients with irritable bowel syndrome. ${ }^{194}$ An operative sphincteroplasty of the pancreatic duct, however, renders Nardipositive patients Nardi-negative. ${ }^{185}$

The development of transendoscopic papillary manometry has provided a method for direct assessment of sphincter of Oddi motility. ${ }^{75} \mathrm{~A}$ spectrum of manometric abnormalities has been identified in patients with post-cholecystectomy pain by means of this technique. ${ }^{195}$ High frequency of phasic contractions ('tachyoddia'), raising of baseline pressure, paradoxical response of the sphincter to CCK and altered direction of phasic waves have all been described..$^{81} 195$ The therapeutic implications of these changes have yet to be determined, but preliminary studies suggest that some patients with sphincter of Oddi dysfunction may benefit from endoscopic sphincterotomy. ${ }^{196}$ If pancreatic duct obstruction contributes to the pain, however, an operative double sphincteroplasty seems likely to give a better result. ${ }^{185}$.

\section{Conclusion}

Before the advent of modern research techniques, knowledge of the physiology and pathophysiology of biliary motility was rudimentary. Now hormone and receptor assay, ultrasonography, cholecystography and endoscopic mano- metry have generated important new data. Although primarily mediated through CCK, gall bladder emptying and refilling are the net result of a whole symphony of stimulatory and inhibitory agents. Opening of the sphincter of Oddi, once thought to be a simple passive relaxation, is a highly synchronised, dynamic and propulsive event. What is apparent from this review is that there is potential for many other hormonal, neurological, and pharmacological mechanisms in the regulation of biliary motility. Furthermore, recognition of pathophysiological mechanisms will lead to accurate diagnosis and treatment of symptomatic patients. More importantly, virtually nothing is understood of the molecular events that occur beyond the cell membrane within biliary smooth muscle once the events of gall bladder emptying have been provoked, and further research is required in this area.

Now that the treatment of biliary disorders is no longer the private estate of the surgeon, it behoves all who endeavour to treat patients with gall stones, acalculous cholecystitis, biliary dyskinesia and papillary stenosis to develop a better understanding of these complex physiological processes.

Boyden EA. The comparative anatomy of the sphincter of Oddi in mammals, with special reference to the choledochoduodenal junction in man. In: Taylor W, ed. The biliary system, a symposium of the NATO advanced study institute. Oxford: Blackwell Scientific Publications, 1965: 15-40.

2 Mann FC, Foster JP, Brimhall SD. The relation of the common bile duct to the pancreatic duct in common domestic and laboratory animals. F Lab Clin Med 1920; 5 : domest

3 Hogan WJ, Dodds WJ, Geenen JE. The biliary tract. In: Christensen J, Wingate DL, eds. A guide to gastrointestinal motility. London: Wright PSG, 1983: 157-97.

4 Boyden EA. The anatomy of the choledochoduodenal junction in man. Surgery 1957; 104: 641-52.

5 Torsoli A, Ramorino ML, Palagi L, et al. Observations roentgen-cinematographiques et electromanometriques sur la motilite des voies biliares. Sem Hop Paris 1961; 37: $790-802$.

6 Hess W. Manometry and radiography in the biliary system during surgery. In: Demling L, Classen M, eds. Endoscopic sphincterotomy of the papilla of Vater. Proc of the International Workshop of the World Congress of Gastroenterology. Munich: Georg Thieme, 1976: 19-23.

7 Toouli J. Sphincter of Oddi motility. Br $\mathcal{F}$ Surg 1984; 71: 251-6.

8 Kern MK, Nakaya M, Dodds WJ, Layman RD, Hogan WJ. Pressure kinetics of the biliary tract in conscious opossums Pressure kinetics of the biliary tract in consciol

9 Hallenbeck GA. Biliary and pancreatic pressures. In: The Handbook of Physiology, section 6, The Alimentary Canal Vol 2. Secretion Code CD: ed. American Physiological Society. Washington DC: 1968: 1007-25.

10 Lanzini A, Jazrawi RP, Northfield TC. Simultaneous quantitative measurements of absoluter gallbladder storage and emptying during fasting and eating in humans. Gastroenterology 1987; 92: 852-61.

11 LaMorte WW, Schoetz DJ Jr, Birkett DH, Williams LF Jr. The role of the gallbladder in the pathogenesis of cholesterol gallstones. Gastroenterology 1979; 77: 580-92.

12 Lawson M, Everson GT, Klingensmith W, Kern F Jr. Coordination of gastric and gallbladder emptying after

13 Ivy AC, Oldberg E. A hormone mechanism for gall-bladder contraction and evaculation. Am $\mathcal{f}$ Physiol 1928; 86: 599cont 613 .

14 Mutt V, Jorpes JE. Structure of porcine cholecystokininpancreozymin. 1. Cleavage with thrombin and with

15 Thompson JC, Fender HR, Ramus NI, Villar HV, Rayford PL. Cholecystokinin metabolism in man and dogs. Ann Surg 1975; 182: 496-504

16 Sakamoto T, Fujimura M, Newman J, Zhu X-G, Greeley GH Jr, Thompson JC. Comparison of hepatic elimination of different forms of cholecystokinin in dogs. Bioassay and radioimmuno assay comparison of cholecystokinin-sulfate and -33-sulfate. $\mathcal{F}$ Clin Invest 1985; 75: 280-5.

17 Eysselein VE, Eberlein GA, Hesse WH, Singer MV, Goebel H, Reeve JR Jr. Cholecystokinin-58 is the major form of circulating cholecystokinin in canine blood. $\mathcal{F} \mathrm{Biol} C \mathrm{Chem}$ 1987; 262: 214-7. 
18 Owyang C, May D, Louie DS. Trypsin suppression of pancreatic enzyme secretion. Differential effect on cholecystokinin release and the enteropancreatic reflex. Gastroenterology 1986; 91: 637-43.

19 Folsch UR, Cantor P, Wilms HM, Schafmayer A, Becker HD, Creutzfeldt W. Role of cholecystokinin in the negative feedback control of pancreatic enzyme secretion in conscious rats. Gastroenterology 1987; 92: 449-58.

20 Gomez G, Lluis F, Guo Y-S, Greeley GH Jr, Townsend CM $\mathrm{Jr}$, Thompson JC. Bile inhibits release of cholecystokinin and neurotensin. Surgery 1986; 100: 363-8.

21 Lilja P, Fagan CJ, Wiener I, et al. Infusion of pure cholecystokinin in humans. Correlation between plasma concentrations of cholecystokinin and gallbladder size. Gastroenterology 1982; 83: 256-61.

22 Wiener I, Inoue K, Fagan CJ, Lilja P, Watson LC Thompson JC. Release of cholecystokinin in man. Correlation of blood levels with gallbladder contraction. Ann Surg 1981; 194: 321-7.

23 Fried GM, Ogden WD, Swierczek J, Greeley GH Jr, Rayford PL, Thompson JC. Release of cholecystokinin in conscious dogs: correlation with simultaneous measurements of gallbladder pressure and pancreatic protein secretion. Gastroenterology 1983; 83: 1113-9.

24 Jazrawi RP, Northfield TC. Effects of a pharmacological dose of cholecystokinin on bile acid kinetics and biliary cholesterol saturation in man. Gut 1986; 27 : 355-62.

25 Jansson R. Effects of gastrointestinal hormones on concentrating function and motility in the gallbladder. Acta Physiol Scand 1978; 456 (suppl): 1-38.

26 Steigerwalt RW, Goldfine ID, Williams JA. Characterization of cholecystokinin receptors on bovine gallbladder membranes. Am f Physiol 1984; 247: 709-14.

27 Williams JA, Bailey A. High-affinity cholecystokinin binding is dependent on cellular metabolism [Abstract]. Can $\mathcal{f}$ is dependent on cellular metabolism [

28 Grider JR, Makhlouf GM. Regional and cellular heterogeneity of cholecystokinin receptors mediating muscle contaction in the gut. Gastroenterology 1987; 92: 175-80.

29 Shook JE, Lemcke PK, Burks TF. Contrasting characteristics of CCK receptors in guinea pig ileum (GPI) \& 1068 .

30 Schjoldager B, Molero X, Miller LJ. Functional and biochemical characterization of the human gallbladder muscularis cholecystokinin receptor. Gastroenterology 1989; 96: 1119-25.

31 Crochelt RF, Peikin SR. Effect of nifedipine and extracellular calcium on spontaneous and potassium-stimulated bovine gallbladder muscle contraction [Abstract]. Gastroenterology 1987; 92: 1799.

32 Malagelada J-R, Holtermuller KH, Sizemore GW, Go VLW. The influence of hypercalcemia on basal and cholecystokinin-stimulated pancreatic, gallbladder, and gastric functions in man. Gastroenterology 1976; 71: $405-8$.

33 Liedberg G. The effect of vagotomy on gall bladder and duodenal pressures during rest and stimulation with cholecystokinin. Acta Chir Scand 1969; 135: 695-700.

34 Inberg MV, Vuorio M. Human gallbladder function after selective gastric and total abdominal vagotomy. Acta Chir Scand 1969; 135: 625-33.

35 Traynor OJ, Byrne PJ, Keegan B, Hennessy TPJ. Effect of vagal denervation on canine gallbladder motility. Brf Surg 1987; 74: 850-4.

36 Yau WM, Youther ML. Modulation of gallbladder motility by intrinsic cholinergic neurons. Am $\mathcal{f}$ Physiol 1984; 247 : $662-6$.

37 Fisher RS, Rock E, Malmud LS. Gallbladder emptying response to sham feeding in humans. Gastroenterology

38 Strah KM, Pappas TN, Melendez RL, Debas HT. Contrasting cholinergic dependence of pancreatic and gallbladder responses to cholecystokinin. Am F Physiol 1986; 250: 665-9.

39 Lennard TWJ, Farndon JR, Taylor RMR. Acalculous biliary pain: Diagnosis and selection for cholecystokinin test for pain reproduction. BrF Surg 1984; 71: 368-70.

40 Valenzuela JE, Wash JH, Isenberg JI. Effect of gastrin on pancreatic enzyme secretion and gallbladder emptying in man. Gastroenterology 1976; 71: 409-11.

41 Cantor P, Petrojijevic L, Pedersen JF, Worning H. Cholecystokinetic and pancreozymic effect of $\mathrm{O}$-sulfated gastrin compared with non-sulfated gasrin and cholecystokinin Gastroenterology 1986; 91: 1154-63.

42 Jansson R, Svanvik J. Effects of intravenous secretin and cholecystokinin on gallbladder net water absorption and motility in the cat. Gastroenterology 1977; 72: 639-43.

43 Chowdhury JR, Berkowitz JM, Praissman M, Fara JW. Interaction between octapaptide-cholecystokinin, gastrin, and secretin on cat gallbladder in vitro. Am $\mathcal{F}$ Physiol 1975; 229: 1311-5.

44 Ryan J, Cohen S. Interaction of gastrin I, secretin, and cholecystokinin on gallbladder smooth muscle. Am $\mathcal{F}$ Physiol 1976; 230: 553-6.

45 Mate L, Sakamoto T, Greeley GH Jr, Thompson JC. Effect of substance $P$ on contractions of the gallbladder. Surg Gynecol Obstet 1986; 163: 163-6.

46 Lonovics J, Varro V, Thompson JC. The effect of cholecystokinin and substance $P$ antagonists on cholecystokinin- and substance P-stimulated gallbladder contraction [Abstract]. Gastroenterology 1985; 88: 1480

47 Takahashi I, Suzuki T, Aizawa I, Itoh Z. Comparison of gallbladder contractions induced by motilin and cholecystokinin in dogs. Gastroenterology 1982; 82: 419-24.
48 Fujimura M, Sakamoto T, Khalil T, Greeley GH Jr, Townsend CM Jr, Thompson JC. Physiologic role of neurotensin in gallbladder contraction in the dog. Surg Forum 1984; 35: 192-4

49 Walker JP, Khalil T, Wiener I, Fagan CJ, Townsend CM Jr, Greeley JH Jr, Thompson JC. The role of neurotensin i human gallbladder motility. Ann Surg 1985; 201: 678-83.

50 Waldman DB, Zfass AM, Makhlouf GM. Stimulatory $\left(\mathbf{H}_{1}\right)$ and inhibitory $\left(\mathbf{H}_{2}\right)$ histamine receptors in gallbladder muscle. Gastroenterology 1977; 72: 932-6.

51 Adrian TE, Mitchenere P, Sagor G, Bloom SR. Effect of pancreatic polypeptide on gallbladder pressure and hepatic bile secretion. Am $\mathcal{F}$ Physiol 1982; 242: 204-7.

52 Conter RL, Roslyn JJ, DenBesten L, Taylor IL. Pancreatic polypeptide enhances postcontractile gallbladder filling in polypeptide enhances postcontractile gallbladder
the prairie dog. Gastroenterology 1987; 92: 771-6.

53 Lonovics J, Guzman S, Devitt P, et al. Release of pancreatic polypeptide in humans by infusion of cholecystokinin. Gastroenterology 1980; 79: 817-22.

54 Ryan J, Cohen S. Effect of vasoactive intestinal polypeptide on basal and cholecystokinin-induced gallbladde pressure. Gastroenterology 1977; 73: 870-2.

55 Strah KM, Melendez RL, Pappas TN, Debas HT. Interac tions of vasoactive intestinal polypeptide and cholecystokinin octapeptide on the control of gallbladder contraction. Surgery 1986; 99: 469-73.

56 Lonovics J, Devitt P, Rayford PL, Thompson JC. Actions of VIP, somatostatin and pancreatic polypeptide on gallbladder tension and CCK-stimulated gallbladder contraction in vitro. Surg Forum 1979; 30: 407-9.

57 Ricci GL, Fevery J. Cholestatic action of somatostatin in the rat: Effect of the different fractions of bile secretion. rat: Effect of the different fractorogy 1981; 81:552-62.

58 Fisher RS, Rock E, Levin G, Malmud L. Effects of somatostatin on gallbladder emptying. Gastroenterology

59 Conter RL, Roslyn JJ, Taylor IL. Effects of peptide YY on gallbladder motility. Am F Physiol 1987; 252: 736-41.

60 Hasimoto T, Poston GJ, Greeley GH Jr, Thompson JC. CGRP inhibits gallbladder contractility. Surgery 1988; 104 419-23.

61 Hashimoto T, Poston GJ, Gomez G, Tatemoto K, Greeley $\mathrm{GH}$, Thompson JC. The effect of pancreastatin on cholecystokinin stimulated gallbladder contraction in vivo and in vitro [Abstract]. Gastroenterology 1988; 94 (suppl): A176.

62 Bourke JB, Ritchie HD. The pressure profile of the sphincter of Oddi in man and the pig [Abstract]. BrF Surg 1970; 57: 848 .

63 Nebel OT. Manometric evaluation of the papilla of Vater. Gastrointest Endosc 1975; 21: 126-8.

64 Potter JC, Mann FC. Pressure changes on the biliary tract. Am $\mathcal{F}$ Med Sci 1926; 171: 202-17.

65 Lueth HC. Studies on the flow of bile into the duodenum and the existence of a sphincter of Oddi. Am $\mathcal{F}$ Physiol 1931; 99: 237-52.

66 Caroli J, Porcher P, Peguigot G, Dellatre M. Contribution of cineradiography to study of the function of the human biliary tract. Am f Dig Dis 1960; 5: 677-96.

67 Cushieri A, Hughes JH, Cohen M. Biliary pressure studies during cholecystectomy. Brf Surg 1972; 59: 267-73.

68 Mochinaga N, Sarna SK, Condon RE, Dodds WJ, Matsumoto T. Gastroduodenal regulation of common bile duct flow in the dog. Gastroenterology 1988; 94: 755-61.

69 Debas HT, Yamagishi T. Evidence for a pyloro-cholecystic reflex for gallbladder contraction. Ann Surg 1979; 190: reflex for

70 Webb TH, Lillemoe KD, Pitt HA. Gastro-sphincter of Oddi reflex. Am F Surg 1988; 155: 193-8.

71 Persson CGA, Ekman M. Effect of morphine, cholecystokinin and sympathomimetics on the sphincter of Oddi and intramural pressure in cat duodenum. Scand $\mathcal{F}$ Gastroenterol 1972; 7: 345-51.

72 Crema A, Berte F. Actions of sympathomimetic drugs on the isolated junction of the bile duct and duodenum. $\mathrm{Br} F$ Pharmacol Chemother 1963; 20: 221-9.

73 Ono K, Watanabe N, Suzuki K, Tsuchidea H, Sugiyama Y, Abo M. Bile flow mechanisms in man. Arch Surg 1968; 96: 869-74.

74 Muller EL, Lewinski MA, Pitt HA. The cholecystosphincter of Oddi reflex. $\mathcal{F}$ Surg Res 1984; 36: 377-83.

75 Geenen JE, Hogan WJ, Doods WJ, Stewart ET, Arndorfer RC. Intraluminal pressure recording from the human sphincter of Oddi. Gastroenterology 1980; 78: 317-24.

76 LaMorte WW, Gaca JM, Wise WE, Birkett DH, Williams LF. Choledochal sphincter relaxation in response to histamine in the primate. $F$ Surg Res $1980 ; 28: 373-8$.

77 Behar J, Biancani P. Effects of cholecystokinin and the octapaptide of cholecystokinin on the feline sphincter of Oddi and gallbladder. F Clin Invest 1980; 66: 1231-9.

78 Sarles JC, Devaus MA, Echinard C, Castagnini A. Action of Cholecystokinin and caeurulein on the rabbit sphincter of Oddi. Digestion 1976; 14: 415-23.

79 Becker JM, Moody FG, Zinsmeister AR. Effect of gastrointestinal hormones on the biliary sphincter of the opossum. Gastroenterology 1982; 82: 1300-7.

80 Pitt HA, Doty JE, DenBesten L, Kuchenbecker SL. Altered sphincter of Oddi phasic activity following truncal vagotomy. F Surg Res 1982; 32: 598-607.

81 Toouli J, Geenen JE, Hogan WJ, Dodds WJ, Arndorfer RC. Sphincter of Oddi motor activity: A comparison between Sphincter of Oddi motor activity: A comparison between
patients with common bile duct stones and controls. Gastroenterology 1982; 82: 111-7.

82 Watts JM, Dunphy JE. The role of the common bile duct in biliary dynamics. Surg Gynecol Obstet 1966; 122: 1207-18. 
83 Sarles JC, Midejean A, Deveaux MA. Electromyography of the sphincter of Oddi. Am $\mathcal{F}$ Gastroenterol 1975; 63 :

84 Toouli J, Dodds WJ, Honda R, et al. Motor function of the opossium sphincter of Oddi. $\mathcal{F}$ Clin Invest 1983; 71 : 208 20.

85 Scott RB, Strasberg SM, El-Sharkawi TY, Diamant NE Fasting canine biliary secretion and the sphincter of Oddi. Gastroenterology 1984; 87: 793-804.

86 Whitaker LR. The mechanism of the gallbladder. Am $\mathcal{J}$ Physiol 1926; 78: 411-36.

87 Sandblom P, Voegtlen WL, Ivy IC. The effect of CCK on the choledochoduodenal mechanism (sphincter of Oddi). $A m \mathcal{F}$ Physiol 1935; 113: 175-80.

88 Lin TM, Spray GF. Effect of pentagastrin, cholecystokinin, caerulin and glucagon on the choledochal resistance and bile flow in dogs [Abstract]. Gastroenterology 1969; 56: 1178 .

89 Behar J. Effect of 5-hydroxytryptamine (5-HT) on the feline sphincter of Oddi (SO): Evidence for a PG inhibitory receptor [Abstract]. Gastroenterology 1980; 78: 1139.

90 Muller EL, Grace PA, Conter RL, Roslyn JJ, Pitt HA Influence of motilin and cholecystokinin on sphincter of Oddi and duodenal motility. Am $\mathcal{F}$ Physiol 1987; 253: 679 83.

91 Behar J, Biancani P. Neural control of the sphincter of Oddi. Physiologic role of encephalins on the regulation of basa sphincter of Oddi motor activity in the cat. Gastroenterology 1984; 86: 134-41.

92 Doty JE, Pitt HA, Kuchenbecker SL, DenBesten L. Effect of gallbladder filling and cholecystokinin on the prairie do sphincter of Oddi. Surg Forum 1981; 32: 148-50.

93 Bertaccini G, De Caro G, Endean G. The actions of caerulin on the smooth muscle of the gastrointestinal tract and gallbladder. $B r \mathcal{F}$ Pharmacol 1968; 4: 291-310.

94 Agosti A, Mantovani P, Mori L. Actions of caerulein and related substances on the sphincter of Oddi. NaunySchmiedbergs. Arch Pharmakol 1971; 208: 114-8.

95 Coelho JC, Moody FG, Senninger N. A new method for correlating pancreatic and biliary duct pressures and correlating pancreatic and biliary duct pressures and
sphincter of Oddi electromyography. Surgery 1985; 97 : 342-9.

96 Behar J, Biancani P. Effects and mechanisms of action of motilin on the cat sphincter of Oddi. Gastroenterology 1988

97 Conter RL, Roslyn JJ, Muller EL, et al. Effect of pancreatic polypeptide on gallbladder filling. $\mathcal{F}$ Surg Res 1985; 38: 461-7.

98 Conter RL, Roslyn JJ, Taylor IL. Effects of peptide YY on gallbladder filling. Am $\mathcal{F}$ Physiol 1987; 252: 736-41.

99 Tatemoto $\mathrm{K}$, Mutt $\mathrm{V}$. Isolation of two novel candidate hormones using a chemical method for finding naturally occurring polypeptides. Nature $1980 ; 285: 417-8$.

100 Tatemoto IK. Isolation and characterization of peptide YY (PYY), a candidate gut hormone that inhibits pancreatic exocrine secretion. Proc Natl Acad Sci USA 1982; 79: 2514-8.

101 Lluis F, Fujimura M, Lonovics J, et al. Peptide YY and gallbladder contraction. Gastroenterology 1988; 94: 1441-6.

102 Grace PA, Couse N, Pitt HA. Peptide YY inhibits cholecystokinin-stimulated sphincter of Oddi activity in the prairie dog. Surgery $1988 ; 1-4: 546-52$.

103 Lillemoe KD, Webb TH, Pitt HA. Neuropeptide Y: A candidate neurotransmitter for biliary motility. F Surg Res 1988; 45: $254-60$.

104 Kyosola K. Sympatho-adrenergic neurla control of the sphincter of Oddi of the cat and dog. Tohoku $\mathcal{F}$ Exp Med 1979; 127: 113-7.

105 Persson CGA. Adrenergic, cholecystokinetic and morphineinduced effects on extra-hepatic biliary motility. Acto Physiol Scand 1972; 383 (suppl): 4-32.

106 Rothman MM. Anatomy and physiology of the gallbladder and bile ducts. Gastroenterology $1965 ; 3$ : 567-89.

107 Persson CGA. Adrenoreceptor functions in the cat choledocho-duodenal junction in vitro. $\mathrm{Br} \mathcal{F}$ Pharmacol 1971; 42: 447-61.

108 Benevantano TC, Rosen RG, Schein CJ. The physiologica effect of acute vagal section on canine biliary dynamics. I Surg Res $1969 ; 9 ; 331-4$.

109 Williams RD, Huang TT. The effect of vagotomy on biliary pressure. Surgery 1969; 66: 353-6.

110 Hopton D, White TT. Effect of hepatic and celiac vagal stimulation on common bile duct pressure. Am $\mathcal{F}$ Dig Dis 1972; 16: 1095-101.

111 Tansey MJ, Innes DL, Martin JS, Kendal FM. An evaluation of neural influences on the sphincter of Oddi in the dog. Dig Dis 1974; 19: 423-37.

112 Helm JF, Venu RP, Geenen JE, et al. Effects of morphine on the human sphincter of Oddi. Gut 1988; 29: 1402-7.

113 Economou G, Ward-McQuaid JN. A cross-over comparison of the effect of morphine, pethidine, pentazocine, and of the effect of morphine, pethine, pentazocine,

114 Bergh GS. The sphincter mechanism of the common bile duct in human subjects. Its reactions to certain types of stimulation. Surgery 1942; 11: 299-330.

115 Guelrud M, Mendoza S, Rossiter G, Ramirez L, Barkin J. Effect of nifedipine on sphincter of Oddi motor activity: Studies in healthy volunteers and patients with biliary dyskinesia. Gastroenterology 1988; 95: 1050-5.

116 Staritz M. Pharmacology of the sphincter of Oddi. Endoscopy 1988; 20: $171-4$

117 Staritz M, Poralla T, Manns $M$, Ewe $K$, Meyer zum Buschenfelde $\mathrm{KH}$. Investigation of the effect of moder morphine-like analgesics on the sphincter of Oddi. Dig Dis Sci 1985; 30: 796-801.
118 Chessick KC, Black S, Hoyer SJ. Spasm and operative cholangiography. Arch Surg 1975; 110: 53-7.

119 Wyatt AP. The relationship of the sphincter of Oddi to the stomach, duodenum and gallbladder. $\mathcal{F}$ Physiol $1967 ; 193$ : $225-41$.

120 Ryan TD, Pellergrini CA, Broderick WC, VanDyke DC Way LW. Effects of anaesthesia on biliary motility in the prairie dog. Surg Forum 1982; 33: 209-13.

121 Grace PA Whb TH, Romano PJ Lillemo KD, Pitt HA. Ketamine inhibits sphincter of Oddi phasic wave amplitude. Curr Surg 1987; 44: 403-5.

122 Lilja P, Wiener I, Inoune K, Priano LL, Greeley G Thompson JC. Effect of anesthetic agents on the release of cholecystokinin. Surg Forum 1982; 33: 130-2.

123 Honda R, Toouli J, Dodds WJ, Sarna S, Hogan WJ, Itoh Z. Relationship of sphincter of Oddi spike bursts to gastroactivity in conscious opossums. $\mathcal{F}$ Clin Invest 1982; 69: 770-8.

124 Cole WH. Relation of gastric content to the physiology of the common duct sphincter. Am $\mathcal{F}$ Physiol $1925 ; 72$ : 39-42.

125 Doubilet H, Colp R. Resistance of the sphincter of Oddi in the human. Surg Gynecol Obstet 1937; 64: 622-33.

126 Best RR, Hicken NF. Non operative management of remaining common duct stones. $\mathscr{F} A M A$ 1938;110: 1257-61.

127 Grace PA, Romano PJ, Pitt HA. Duodenal acidification inhibits sphincter of Oddi motility in the prairie dog. f Surg Res 1987; 43: 68-74.

128 Grace PA, Pitt HA. Cholecystectomy alters the hormona response of the sphincter of Oddi. Surgery 1987; 102: 186

129 Webb TA, Lillemoe KD, Pitt HA. Intraduodenal protein stimulates resting but inhibits CCK-stimulated sphincter of Oddi motility [Abstract]. Gastroenterology 1987; 92 : 1687.

130 Liddle RA, Green GM, Conrad CK, Williams JA. Proteins but not amino acids, carbohydrates, or fats stimulate CCK secretion in the rat. Am 7 Physiol 1986; 251: 243-8.

131 Pomeranz IS, Davison JS, Shaffer EA. The effects of prosthetic gallstones on gallbladder function and bile composition. F Surg Res 1986; 41: 47-52.

132 Maudgal DP, Kupfer RM, Zentler-Munro PL, Northfield TC. Postprandial gall-bladder emptying in patients with TC. Postprandial gall-bladder emptying

133 Northfield TC, Kupfer RM, Maudgal DP, et al. Gall-bladder sensitivity to cholecystokinin in patients with gall stones. BrMed F 1980; 280: 143-4.

134 Feeley TM, Lennon F, Clanachan AS, Scott GW. Motility in normal and diseased human gallbladder [Abstract]. $\mathrm{Br} f$ Surg 1984; 71 : 988 .

135 Roslyn JJ, DenBesten L, Pitt HA, Kuchenbecker S, Polare JW. Effects of cholecystokinin on gallbladder stasis and cholesterol gallstone formation. F Surg Res 1981; 30: $200-4$.

136 Fisher RS, Stelzer F, Rock E, Malmud LS. Abnorma gallbladder emptying in patients with gallstones. Dig Dis Sci 1982; 27: 1019-24

137 Thompson JC, Fried GM, Ogden MD, et al. Correlation between release of cholecystokinin and contraction of the gallbladder in patients with gallstones. Ann Surg 1982; 195 $670-6$

138 Upp JR Jr, Nealon WH, Singh P, et al. Correlation of cholecystokinin receptors with gallbladder contractility in patients with gallstones. Ann Surg 1987; 205: 641-8.

139 Doty JE, Pitt HA, Kuchenbecker SL, Denbesten L. Impaired gallbladder emptying before gallstone formation in the priarie dog. Gastroenterology 1983; 85: 168-74.

140 Forgars IC, Maisey MN, Murphy GM, Dowling RH. Influence of gallstones and urodeoxycholic acid therapy 307 .

141 Bobba VR, Krishnamurthy GJ, Kingston C, Turner FE, Brown PH, Langrell K. Gallbladder dynamics induced by a fatty meal in normal subjects and patients with gallstones. f Nucl Med 1984; 25: $21-4$.

142 Pomeranz IS, Shaffer EA. Abnormal gallbladder emptying in a subgroup of patients with gallstones. Gastroenterolog a subgroup of pa

143 Pitt HA, Roslyn JJ, Kuchenbecker SL, Doty JE, DenBesten $L$. The role of cystic duct resistance in the pathogenesis of cholesterol gallstones. F Surg Res 1981; 30 :

144 Pitt HA, Doty JE, DenBesten L, Kuchenbecker SL. Stasi before gallstone formation: Altered gallbladder compliance or cystic duct resistance? Am F Surg 1982; 143: $144-9$.

145 Kotwall CA, Calanachan AS, Baer HP, Scott GW. Effects of prostaglandins on motility of gallbladders removed from patients with gallstones. Arch Surg 1984; 119: 709-12.

146 Katoaka S, Syoji K-I. Elevated cholecystokinin-like activity with cholecystolithiasis. Tohoku F Exp Med 1985; 145: 395-402.

147 Meyer PD, DenBesten L, Gurll NJ. Effects of cholesterol gallstone induction on gallbladder function and bile salt poo
size in the prairie dog model. Surgery $1978 ; 83: 599-604$.

148 Pellegrini CA, Ryan T, Broderick W, Way LW. Gallbladder filling and emptying during cholesterol formation in the prairie dog. A cholescintigraphic study. Gastroenterology

149 Poston GJ, Singh P, Draviam E, Yao CZ, Thompson JC Gallstone formation is associated with diminished gallbladder motility [Abstract]. Br F Surg 1988; 75: 616 .

150 Roslyn JJ, Pitt HA, Mann LL, Ament ME, DenBesten L. Gallbladder disease in patients on long-term parenteral nutrition. Gastroenterology 1983; 84: 148-54.

151 Pitt HA, Doty JE, DenBesten L. Decreased intragallbladde pressure response to cholecystokinin-octapeptide follow- 
ing vagotomy and pyloroplasty. F Surg Res 1983; 35: 32531.

152 Holzbach RT. Gallbladder stasis: Consequence of long-term parenteral hyperalimentation and risk factor for cholelithiasis. Gastroenterology 1983; 84: 1055-8.

153 Roslyn JJ, Berquist WE, Pitt HA, et al. Increased risk of gallstones in children receiving total parenteral nutrition. Pediatrics 1983; 71: 784-9.

154 King DR, Ginn-Pease ME, Lloyd TV, Hoffman J, Hohenbrink K. Parenteral nutrition with associated cholelithiasis: another iatrogenic disease of infant and children. F Pediatr Surg 1987; 22: 593-6.

155 Williamson RCN. Acalculous disease of the gallbladder. Gut 1988; 29: 860-72.

156 Doty JE, Pitt HA, Porter-Fink V, DenBesten L. Cholecystokinin prophylaxis of parenteral nutrition-induced gallbladder disease. Ann Surg 1985; 201: 76-80.

157 Boyden EA, Grantham SA. Evaluation of the gallbladder in old age. Surg Gynecol Obstet 1926; 62: 34-42.

158 Portis SA, King JC. The gastrointestinal tract in the aged. FAMA 1952; 148: 73-9.

159 Khalil T, Walker JP, Wiener I, Fagan CJ, Townsend CM Jr, Greeley GH Jr, Thompson JC. Effect of aging on gallbladder contraction and release of cholecystokinin-33 in humans. Surgery 1985d; 98: 423-9.

160 Poston GJ, Singh P, Draviam GJ, Upp JR Jr, Thompson JC Development and age related changes in pancreatic cholecystokinin receptors and duodenal cholecystokinin in guines pigs. Mech Ageing Dev 1988; 46: 59-66.

161 Khalil T, Mate L, Greeley GH Jr, Thompson JC. Decreased gallbladder responsiveness to CCK-8 in aged rabbits [Abstract]. Gastroenterology 1984; 86: 1134

162 Poston GJ, Singh P, MacLellan DG, et al. Age related changes in gallbladder cholecystokinin receptor population in the guinea pig. Mech Ageing Dev 1988; 46: 225-36.

163 Jouppila P, Heikkinen J, Kirkinen P. Contractility of maternal and fetal gallbladder: An ultrasonic study. $\mathcal{F}$ Clin maternal and fetal gallbladder:

164 Denehy CM, Ryan JR. Development of gallbladder contractility in the guines pig. Pediatr Res 1986; 20: 214-7.

165 Lotveit T, Osnes M, Larsen S. Recurrent biliary calculi. Duodenal diverticula as a predisposing factor. Ann Surg 1982; 196: 30-2.

166 Viceconte G, Viceconte GW, Bogliolo G. Endoscopic manometry of the sphincter of Oddi in patients with and without uxtapapillary duodenal diverticula. Scand $\mathcal{F}$ Gastroenterol 1984; 19: 329-33.

167 Poston GJ, Draviam EJ, Yao CZ, Upp JR Jr, Alexander RW, Thompson JC. The effect of age and cholecystokinin on Tallstone formation in the guinea pig [Abstract]. Gastroenterology 1987; 92: 1765 .

168 National Center for Health statistics: Detailed diagnoses and surgical procedures for patients discharged from short stay hospitals, 1979. Health and human services, Public Health hospitals, 1979.

169 Oddi R. D'une disposition a sphincter speciale de l'ouverture du canal choledoque. Arch Ital Biol 1887; 8: 317-32.

170 Judd ES, Mann FC. The effect of removal of the gallbladder. Surg Gynecol Obstet 1917; 24: 437-42.

171 Mahour GH, Wakim KG, Soule EH, Ferris DO. Effect of cholecystectomy on the biliary ducts in the dog. Arch Surg 1968; 97: $570-4$.

172 Mahour GH, Wakim KG, Ferris DO, Soule EH. The common bile duct after cholecystectomy: a comparison of common bile ducts in patients who have intact biliary systems with those in patients who have undergone cholecystectomy. Ann Surg 1967; 166: 964-7.

173 Longo MJ, Hodgson JR, Ferris DO. Size of the common bile duct following cholecystectomy. Ann Surg 1967; 165: 250-3.

174 Meier PB, Silvis SE, Dreyer M, Ansel H, Vennes JA. Bile duct size after cholecystectomy [Abstract]. Gastroenterology 1985; 88: 1499 .

175 Wiener I, Walker JP, Greeley GH, Townsend CM, Thompson JC. Increased release of cholecystokinin with intraduodenal fat after cholecystectomy in dogs. Surg Forum 1984 ; 35: 196-8

176 Bodvall B, Overgaard B. Computer analysis of postcholecystectomy biliary tract symptoms. Surg Gynecol Obstet 1967; 124: 723-32.

177 Moody FG. The postcholecystectomy syndrome. In: Moody FG, Carey LC, Scott Jones R, Kelly KA, Nahrwold DL, Skinner BD, eds. Surgical treatment of digestive disease. Chicago: Year Book Medical Publishers, 1986: 296-305.

178 Hogan WJ, Geenan JE. Biliary dyskinesia. Endoscopy 1988; 20: 179-83.

179 Doubilet H, Mulholland JH. Eight year study of pancreatitis and sphincterotomy. $\mathcal{F} A M A$ 1956; 160: 521-8.

180 Das PN. An experimental study of disturbances of the sphincter of Oddi. F Pathol Bacteriol 1965; 90: 135-50.

181 Reynolds BM. Immediate effects of instrumental dilatation of the ampulla of Vater. Ann Surg 1966; 164: $271-4$.

182 Acosta JM, Civantos F, Nardi GL. Fibrosis of the papilla of Vater. Surg Gynecol Obstet 1967; 124: 787-94.

183 Grage TB, Lober PH, Imamoglu K. Stenosis of the sphincter of Oddi: a review of 50 cases. Surgery 1960; 48: 304-17.

184 Moody FG, Berenson MM, McCloskey DD. Transampulla septectomy for post-cholecystectomy pain. Ann Surg 1977; 186: 415-23.

185 Williamson RCN. Pancreatic sphincteroplasty: indications and outcome. Ann R Coll Surg Engl 1988; 70: 205-11.

186 Moody FG, Becker JM, Potts JR. Transduodena sphincteroplasty and transampullary septectomy for postcholecystectomy pain. Ann Surg 1983; 197:627-36.

187 Ivy AC, Sandblom P. Biliary dyskinesia. Ann Int Med 1934; 8: $115-22$.

188 Macgowan J, Butsch WI, Walters W. Pressure in the common bile duct of man $7 A M A 1936 ; 106: 2227-30$.

189 Colp $\mathrm{R}$. The treatment of postoperative biliary dyskinesia. Gastroenterology $1946 ; 7 ; 414$

190 Dahl-Iverson E, Sorensen AH, Weston-Gaard E. Pressure measurement in the biliary tract in patients after cholecystolithotomy and in patients with dyskinesia. Acta Chir Scand 1958; 114: 181-90.

191 Nardi GL, Acosta JM. Papillitis as a cause of pancreatitis and abdominal pain: Role of evocative test, operative pancreatography and histologic evaluation. Ann Surg 1966; 164: 611-21.

192 Gregg JA, Taddeo AE, Milano AF, et al. Duodenoscopy and endoscopic pancreatography in patients with positive endoscopic pancreatography in patients with positive

193 LoGuidice JA, Gennen JE, Hogan WJ, Dodds WJ. Efficacy of the morphine-prostigmine test for evaluating patients
with suspected papillary stenosis. Dig Dis Sci 1979; 24: with susp

194 Steinberg WM, Salvato RF, Toskes PP. The morphineprostigmine test; is it useful for making clinical decisions? Gastroenterology 1980; 78: 728-31.

195 Toouli J, Roberts-Thompson IC, Dent J, Lee J. Manometric disorders in patients with suspected sphincter of Odd dysfunction. Gastroenterology 1985; 88: 1243-50.

196 Geenen J, Hogan W, Toouli J, Dodds W, Venu R. A prospective randomized study of the efficacy of endoscopic spincterotomy for patients with presumptive sphincter of Oddi dysfunction [Abstract]. Gastroenterology 1984; 86: 1086 